\title{
EKSISTENSI KEBIJAKAN DAERAH YANG DEMOKRATIS DALAM SISTEM PEMERINTAHAN YANG BERSIH BEBAS DARI KORUPSI KOLUSI DAN NEPOTISME STUDI KASUS DI KABUPATEN SUKOHARJO
}

\author{
Juwandono \\ Magister Ilmu Hukum \\ Universitas Muhammadiyah Surakarta
}

\begin{abstract}
$T$ he areapolicies that against with the societyaspiration either higher law andregulation, that way also without the existence of integrity in the area policy making mechanism between the area government and DPRD, generating unclearly democratic area policy existence in the clean government system free from corruption, collusion, nepotism. The research method used is the combination between empires law research and normative law research. The empires law research method done with deep interview and observation, the data collected then analyzed quantitatively. In normative law research method, the collected law institutions analyzed normatively with historical approach, comparative approach, law and regulation approach and conceptual approach. Every approach used as needed. The result and solution of the research are follows: the area regulation about the mechanism of society participation to critics the government's policy is still in concepts and inspection in executive, and there are efforts to open the ways to society participation critically and constructive with Musrenbangdes, Hand phone (HP), Sabtu Pon-an, Forum Ngelengke dan Ngeleke. The hope of clean governments system that free from KKN still haunted by KKN practice indication that not only happen in central government but also can happen in area government. The society participation have significantly enough contribution to prevent and minimize the KKN practice in area policy making but very regrettable that the open give enough significance access to society politic education to produce aspirate, participative and democratic area policy. The used of governance authority in area policy making incorrectly can result fatal and contra productive area policy, so society participant existence is absolutely needed. The citizen's basic right is basic right, and deserves to have law protection and can be defended in any situation to anticipate the effect of area policy making. Based on the result of the research above, can be suggested as follows: to realize the area regulation of society participation to critics the planning, and making of area policy in Sukoharjo Sub-province can be done with creative and dynamic movement to powered the society to participate to eliminating KKN practices in every making of area policy either direct or not direct in Sukoharjo sub-province government so the government can used the government authority to planning and making the area policy with optimal, correct, effective and efficient.
\end{abstract}

Keyword: area policy, democratic, corruption, collusion, and nepotism.
Abstrak
ebijakan-kebijakan daerah yang bertentangan dengan aspirasi masyarakat maupun peraturan perundang-undangan yang lebih tinggi, demikian pula dengan tidak adanya keterpaduan dalam mekanisme pembuatan kebijakan daerah antara kepada daerah dengan DPRD, menimbulkan ketidak jelasan eksistensi kebijakan daerah yang demokratis dalam sistem pemerintahan yang bersih bebas dari korupsi, kolusi dan nepotisme. 


\begin{abstract}
Metode penelitian yang digunakan merupakan kombinasi antara penelitian hukum empiris dengan penelitian hukum normatif. Tipe penelitian hukum empiris dilakukan dengan cara wawancara mendalam dan observasi, data yang terkumpul dianalisis secara kualitatif. Dalam tipe penelitian hukum normatif, bahan hukum yang terkumpul dianalisis secara normatif dengan menggunakan pendekatan historis, pendekatan komparatif, pendekatan peraturan perundang-undangan dan pendekatan konseptual, masing-masing pendekatan dipergunakan sesuai dengan kebutuhannya. Hasil penelitian dan pembahasan adalah sebagai berikut : Perda tentang mekanisme partisipasi masyarakat untuk mengkritisi kebijakan-kebijakan jajaran Pemerintah daerah kabupaten Sukoharjo sampai saat ini masih dalam konsep dan penggodokan di eksekutif, dan ada usaha-usaha untuk merintis dan membuka jalan kearah dapat dilakukannya partisipasi masyarakat secara kritis dan konstruktif melalui Musrenbangdes, Hand phone (HP), Sabtu Pon-an, Forum Ngelengke dan Ngeleke Harapan untuk terwujudnya penyelenggaraan pemerintah yang bersih terbebas dari KKN ternyata masih dihantui dan dibayang-bayangi adanya indikasi praktek KKN tidak hanya dapat terjadi dalam jajaran pemerintah pusat, melainkan dapat pula terjadi dalam jajaran Pemda; Partisipasi masyarakat mempunyai konstribusi yang cukup signifikan untuk mencegah dan mengeliminir terjadinya praktek KKN dalam pembentukan kebijakan-kebijakan daerah, namun patut disesalkan, keterbukaan memberikan akses yang cukup signifikan untuk pendidikan politik rakyat daerah guna menghasilkan kebijakan daerah yang aspiratif, partisipatif dan demokratif, Penggunaan wewenang pemerintahan dalam perencanaan dan pembuatan kebijakan daerah secara tidak tepat dapat berakibat fatal dan kontra produktif dan oleh karenanya partisipasi masyarakat mutlak diperlukan eksistensinya ; Hak asasi warga masyarakat suatu daerah merupakan hak dasar, yang layak memperoleh perlindungan hukum dan dapat dipertahankan dalam keadaan apapun juga, untuk mengantisipasi akibat-akibat yang timbul dari bentuk dan diberlakukannya suatu kebijakan daerah.
\end{abstract}

\title{
Kata Kunci: Kebijakan daerah, Demokratis, Korupsi, Kolusi dan Nepotisme
}

\section{Pendahuluan}

Seiring dengan dilaksanakannya program otonomi daerah, pada umumnya masyarakat mengharapkan adanya peningkatan kesejahteraan dalam bentuk peningkatan mutu pelayanan masyarakat, partisipasi masyarakat yang lebih luas dalam pengambilan kebijakan publik, yang sejauh ini hal tersebut kurang mendapat perhatian dari pemerintahan pusat. Namun kenyataannya sejak diterapkannya Undang-undang No 22 Tahun 1999 tentang Pemerintahan Daerah yang dirubah menjadi UU RI 32 Tahun 2004 dan Undang-undang No 25 Tahun 1999 tentang Perimbangan Keuangan Antar Pemerintah Pusat dan Daerah sejak Oktober 2004 yang dirubah menjadi UU RI NO 33 Tahun 2004 belum menunjukkan perkembangan yang signifikan bagi pemenuhan harapan masyarakat tersebut.

Dalam era transisi desentralisasi kewenangan itu telah melahirkan berbagai penyimpangan kekuasaan atau korupsi, kolusi dan nepotisme (KKN) termasuk didalamnya bidang politik di daerah, KKN yang paling menonjol pasca otonomi daerah antara lain semakin merebaknya kasus-kasus politik uang dalam pemilihan kepala daerah. Berbagai pihak menyoroti realitas otonomi daerah yang rawan terhadap terjadinya $\mathrm{KKN}$ tersebut, dipengaruhi oleh beberapa faktor antara lain :

1. Program otonomi daerah hanya terbatas pada pelimpahan wewenang dalam pembuatan kebijakan, keuangan dan administrasi dari pemerintah pusat ke daerah, tanpa disertai pembagian kekuasaan kepada masyarakat atau tanpa partisipasi masyarakat secara luas

2. Tidak adanya institusi negara yang mampu mengontrol secara efektif penyimpangan wewenang di daerah. Program otonomi daerah telah memotong struktur hirarki 
pemerintahan, sehingga tidak efektif lagi kontrol pemerintah pusat ke daerah karena tidak ada lagi hubungan struktural hirarki pemerintahan.

3. Terjadi indikasi KKN yang cukup krusial antara pemerintah daerah dan DPRD, sehingga kontrol terhadap jalannya penyelenggaraan pemerintah daerah sulit terlaksana, sementara kontrol dari kalangan masyarakat masih sangat lemah.

Berkaitan dengan pelaksanaan otonomi daerah, penyelenggaraan pemerintah daerah yang demokratis dan akuntabel, merupakan isu yang sangat penting dan strategis. Hal tersebut sesungguhnya merupakan konsekuensi logis dari otonomi daerah yang semestinya memungkinkan :

1. Semakin dekatnya pelayanan pemerintah daerah kepada masyarakat;

2. Penyelesaian masalah-masalah di daerah menjadi lebih terfokus dan mandiri;

3. Partisipasi masyarakat menjadi lebih luas dalam pembangunan daerah;

4. Masyarakat melakukan pengawasan lebih intensif terhadap penyelenggaraan pemerintah daerah.

Sebagai ilustrasi pemerintahan kabupaten Sukoharjo secara perposif dipilih sebagai lokasi penelitian hukum empiris, dengan pertimbangan bahwa pemerintahan kabupaten Sukoharjo merupakan salah satu pemerintahan daerah yang mempunyai kedudukan, fungsi dan peranan yang sejajar dengan pemerintahan daerah lainnya, dalan jajaran dan sistem pemerintahan negara kesatuan Republik Indonesia. Demikian pula secara perposif ilustrasi obyek kajian dibatasi khusus eksistensi kebijakan daerah yang demokratis dalam sistem pemerintahan yang bersih bebas dari KKN.

Dari persoalan itu, artikel ini akan membahas mengenai 3 hal yaitu: (1) bagaimanakah realisasi pembuatan kebijakan daerah yang demokratis dalam sistem pemerintahan yang bersih bebas dari korupsi, kolusi dan nepotisme? (2) apakah dalam setiap pembuatan kebijakan daerah telah melibatkan partisipasi masyarakat? (3) Mengapa masyarakat perlu dilibatkan dalam setiap pembuatan dan evaluasi kebijakan daerah?

\section{Metode Penelitian}

Penelitian ini merupakan kombinasi antara penelitian empiris dan penelitian hukum normatif. Masing-masing tipe penelitian tersebut digunakan dengan kebutuhannya.

Penelitian hukum empiris dilakukan melalui observasi dan wawancara mendalam (in depth interviews) dengan para responden dan narasumber yang berkompeten dan terkait dengan masalah yang diteliti (obyek yang diteliti), untuk mendapatkan data primer dan akan dilakukan pula studi kasus.

Penelitian hukum normatif dilakukan dengan mengumpulkan bahan hukum baik primer, sekunder dan atau tersier. Dalam rangka mendapatkan jawaban atau penyelesaian atas masalahmasalah (isu hukum) yang telah dirumuskan, dapat diperguanakn empat model pendekatan penyelesaian masalah yaitu pendekatan peraturan perundang-undangan (statutory approach), pendekatan konseptual (conceptual approach), pendekatan komparatif (comparative approach), dan pendekatan histories (historical approach), yang penerapannya disesuaikan dengan kebutuhan. Semua pendekatan yang disebutkan di atas diterapkan pada lapisan ilmu hukum dogmatik dan atau lapisan hukum teoritik

\section{Hasil Penelitian dan Pembahasan}

\section{Realisasi Pembuatan Kebijakan Daerah yang Demokratis dalam Sistem Pemerintahan yang Bersih Bebas dari Korupsi, Kolusi dan Nepotisme}

Dalam sistem negara kesatuan, eksistensi pemerintahan daerah merupakan sub sistem dalam sistem pemerintahan nasional. Dengan demikian pemerintah daerah merupakan bagian 
yang tak terpisahkan dengan pemerintahan pusat, oleh karenanya prinsip dan paradigma pemerintahan yang bersih bebas dari korupsi, kolusi dan nepotisme yang berlaku terhadap pemerintahan nasional, juga berlaku terhadap pemerintahan daerah pada hakekatnya juga merupakan penyelenggaraan negara, penyelenggaraan daerah (DPRD dan Eksekutif Daerah) juga merupakan penyelenggara negara. ${ }^{1}$

Penyelenggara daerah dan atau penyelenggara negara mempunyai peranan yang sangat menentukan dalam penyelengarakan daerah atau penyelenggara negara untuk mencapai citacita bangsa mewujudkan masyarakat yang adil dan makmmur sebagaimana tercantum dalam UUD $1945 .^{2}$

Untuk mewujudkan penyelenggara daerah dan atau penyelenggara negara yang mampu menjalankan fungsi dan tugasnya secara sungguh-sungguh dan penuh tanggung jawab. Perlu diletakkan asas-asas penyelenggaraan daerah. ${ }^{3}$ Praktek korupsi, kolusi, dan nepotisme tidak hanya dilakukan antar penyelenggara negara dan atau antar penyelenggara daerah melainkan juga antar penyelenggara negara dan atau penyelenggara daerah dengan pihak lain yang dapat merusak sendi-sendi kehidupan bermasyarakat dan berbangsa, sehingga untuk itu diperlukan landasan hukum untuk pencegahannya. ${ }^{4}$

Dari berbagai paparan tersebut dapatlah diketahui bahwa :

1. Eksistensi pemerintahan daerah merupakan sub sistem pemerintahan nasional.

2. Tuntutan dan tantangan untuk terselenggaranya pemerintahan nasional yang bersih bebas dari korupsi, kolusi, dan nepotisme berlaku dan relevan pula bagi pemerintahan daerah.

3. Indikasi terjadinya praktek korupsi, kolusi dan nepotisme tidak hanya dalam jajaran pemerintahan pusat, melainkan juga dalam jajaran pemerintahan daerah.

Penyelenggara negara, termasuk didalamnya penyelenggara daerah adalah penyelenggara negara dan atau penyelenggara daerah yang mentaati asas-asas umum penyelenggaraan negara dan atau daerah dan terbebas dari praktek korupsi, kolusi, dan nepotisme serta perbuatan tercela lainnya. ${ }^{5}$ Korupsi adalah tindak pidana sebagaimana dimaksud dalam ketentuan peraturan perundang-undangan pidana. ${ }^{6}$

Kolusi adalah permufakatan atau kerja sama secara melawan hukum antar penyelenggara negara termasuk didalamnya penyelenggara daerah atau antara penyelenggara negara termasuk didalamnya penyelenggara daerah dengan pihak lain yang merugikan orang lain, masyarakat, negara dan atau daerah. ${ }^{7}$

Nepotisme adalah setiap perbuatan penyelenggara negara termasuk didalamnya penyelenggara daerah secara melawan hukum yang menguntungkan kepentingan keluarganya dan atau kroninya di atas kepentingan masyarakat, berbangsa, bernegara, dan atau daerah.

Asas umum pemerintahan negara yang baik adalah asas yang menjunjung tinggi norma kesusilaan, kepatutan dan norma hukum, untuk mewujudkan penyelenggara negara termasuk didalamnya penyelenggara daerah yang bersih dan bebas dari korupsi, kolusi dan nepotisme. ${ }^{8}$

Dari berbagai uraian tersebut dapatlah diketahui bahwa :

1. Penyelenggara daerah merupakan sub sistem penyelenggara negara.

2. Asas-asas umum penyelenggara negara berlaku juga terhadap penyelenggara daerah.

3. Indikasi praktek korupsi, kolusi dan nepotisme tidak hanya terjadi dalam jajaran pemerintahan nasional semata, melainkan dapat pula terjadi dalam jajaran pemerintah daerah.

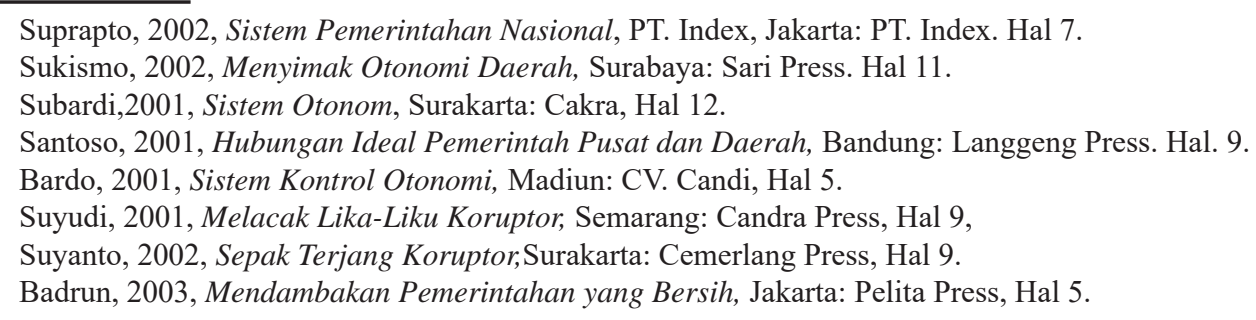


4. Harapan untuk terwujudnya penyelenggara pemerintahan negara yang bersih dan bebas dari korupsi, kolusi, dan nepotisme berlaku pula terhadap penyelenggaraan pemerintah daerah.

5. Penyelenggara daerah meliputi eksekutif daerah dan legislatif daerah.

\section{Aspirasi dan Partisipasi Masyarakat dalam Pembuatan Kebijakan Daerah Pasca Undang-Undang Nomor 32 Tahun 2004}

\section{a. Kebijakan Daerah yang Aspiratif}

Peran serta masyarakat dalam penyelenggaraan negara termasuk didalamnya penyelenggara daerah, merupakan hak dan tanggung jawab masyarakat untuk ikut mewujudkan penyelenggara negara termasuk didalamnya penyelenggara daerah yang bersih. Hubungan dengan penyelenggara negara termasuk didalamnya penyelenggara daerah dengan masyarakat, dilaksanakan dengan berpegang teguh pada asas-asas umum penyelenggaraan negara yang meliputi asas : kepastian hukum, tertib penyelenggaraan negara, kepentingan umum, keterbukaan, proporsionalitas, profesionaliitas dan akuntabilitas. ${ }^{9}$

Peran serta masyarakat diwujudkan dalam bentuk: ${ }^{10}$

1) Hak mencari, memperoleh, dan memberikan informasi tentang penyelenggara negara, termasuk didalamnya penyelenggara daerah.

2) Hak untuk memperoleh pelayanan yang sama dan adil dari penyelenggara negara dan atau dari penyelenggara daerah:

3) Hak menyampaikan saran dan pendapat secara bertanggung jawab terhadap kebijakan penyelenggara negara dan atau terhadap kebijakan penyelenggara daerah.

4) Hak memperoleh perlindungan hukum dalam hal melaksanakan haknya sebagaimana dimaksud dalam huruf a, b dan c tersebut. Demikian pula dalam hal diminta hadir dalam proses penyelidikan, penyidikan, dan sidang pengadilan sebagai saksi pelapor, saksi ahli, sesuai dengan peraturan perundang-undangan yang berlaku. Hak-hak masyarakat untuk berperan serta terhadap kebijakankebijakan negara dan atau kebijakan-kebijakan daerah tersebut, dilaksanakan sesuai dengan ketentuan peraturan perundang-undangan yang berlaku dan dengan mentaati norma agama dan norma sosial lainnya.

Maksud dan tujuan digalakkannya peran serta masyarakat dalam pembentukan dan evaluasi kebijakan daerah, adalah untuk memberdayakan masyarakat dalam rangka mewujudkan penyelenggaraan daerah yang bersih bebas dari korupsi, kolusi dan nepotisme. Dengan hak dan kewajiban yang dimiliki, masyarakat diharapkan dapat lebih bergairah melaksanakan penyelenggaraan daerah dengan tetap mentaati rambu-rambu yang berlaku.

Peran serta masyarakat adalah peran aktif masyarakat untuk ikut serta mewujudkan penyelenggara negara atau penyelenggara daerah yang bersih dan bebas dari korupsi, kolusi dan nepotisme yang dilaksanakan dengan mentaati norma hukum, moral, dan sosial yang berlaku dalam masyarakat. Pada dasarnya masyarakat mempunyai hak untuk memperoleh informasi tentang penyelenggara negara atau penyelenggara daerah, namun hak tersebut tetap harus memperhatikan ketentuan peraturan perundang-undangan yang berlaku, yang memberikan batasan-batasan untuk masalah-masalah tertentu dijamin kerahasiaannya. ${ }^{11}$ (Sunarto, 2002: 11)

9 Supriyadi, 2002, Sistem Pasrtisipasi Modern, Surabaya: PT. Dua Aksara, Hal 8.

10 Sugiri, 2002, Perlindungan Perburuhan, Jakarta: Pelita Press, Hal 6.

11 Sunarto, 2002, Perlindungan Perburuhan, Jakarta: Pelita Press, Hal 11. 
Dari berbagai uraian tersebut dapatlah diketahui bahwa :

1) Setiap kebijakan daerah senantiasa harus aspiratif.

2) Setiap pembuatan kebijakan daerah harus memberikan ruang yang cukup kepada masyarakat untuk berpartisipasi.

3) Partisipasi masyarakat mempunyai andil atau kontribusi yang cukup signifikan untuk mencegah dan mengeliminir melalui DPR atau DPRD. Ketentuan tentang dengar pendapat umum, merupakan sarana yang patut dioptimalkan, sehingga pembentukan peraturan perundang-undangan dan atau kebijakan-kebijakan daerahnya betul-betul mengikut sertakan masyarakat.

Dengan demikian dapat diketahui bahwa untuk menentukan kebijakan daerah yang baik rakyat perlu diberikan akses untuk menyalurkan aspirasinya secara baik, lancar dan transparan melalui wakil-wakil rakyat di DPR maupun DPRD setempat.

\section{b. Kebijakan Daerah yang Demokratis}

Legitimasi rakyat terhadap kebijakan-kebijakan daerah merupakan prasyarat terealisirnya demokratisasi dalam penyelenggaraan pemerintahan daerah. Kebijakan daerah dapat dikatagorikan demokratis apabila penyusunan dan penetapannya telah mendapatkan dukungan rakyat daerah secara proporsional dan komprehensif. Keterlibatan rakyat daerah dalam berpartisipasi terhadap rencana pembentukan dan pelaksanaan kebijakan daerah, akan memberikan nilai tambah tersendiri terhadap kuantitas dan kualitas kebijakan daerah yang bersangkutan.

Syarat minimum demokrasi adalah: ${ }^{12}$

1) Pada prinsipnya setiap orang mempunyai hak untuk dipilih

2) Setiap orang mempunyai hak-hak politik berupa hak atas kebebasan berpendapat dan berkumpul

3) Badan perwakilan rakyat mempengaruhi pengambilan keputusan melalui sarana "(Mede) beslissings recht" (hak untuk ikut memutuskan) dan atau melalui wewenang pengawas.

4) Asas keterbukaan dalam pengambilan keputusan dan sifat keputusan yang terbuka.

5) Pada prinsipnya setiap orang mempunyai hak yang sama dalam pemilihan yang bebas dan rahasia.

6) Pada dasarnya setiap orang mempunyai hak untuk dipilih.

Tampilan asas itu sebenarnya berkaitan dengan asas pengambilan keputusan dalam ketatanegaraan belanda yaitu asas mayoritas. Dalam ketatanegaraan kita prinsip utama dalam pengambilan keputusan adalah asas musyawarah untuk mufakat.

Dalam sistem ketatanegaraan indonesia, khususnya dalam hukum tata negara dan hukum administrasi "keterbukaan" merupakan asas penyelenggaraan pemerintahan yang bertumpu atas asas demokrasi (partisipasi). Demokrasi perwakilan sudah lama dirasakan tidak memadai. Pernyataan seperti yang pernah diucapkan Prof. Mr. R. Boerdisoesetio pada pidato inagurasinya sebagai Guru Gesar Luar Biasa Hukum Tata Negara dan Hukum Tata Pemerintahan pada Fakultas Hukum Universitas Airlangga yang diucapkan pada hari rabu, Tanggal 10 Nopember 1958 kiranya sudah ketinggalan dalam kehidupan demokrasi modern. Dalam pidato tersebut dikatakan :

Sekali anggota-anggota itu terpilih dan berbentuk DPR, maka rakyat yang berdaulat itu tidak pempunyai wewenang lagi untuk mengatakan kemajuan...........

12 M.C. Burkens, 1990, Beginselen Van de Democratische Rechtsstaat, Tjeenk Willik Zwole. In Samenwerking Met Her Nederlands Institute Voor Sociaal en Economisch Rencht. 
Apabila wacana itu diikuti maka setelah rakyat memberikan suaranya pada (hari pemungutan suara), selanjutnya rakyat itu tidak tahu apa-apa lagi tentang pelaksanaan pemerintahan. Bagi suatu negara demokrasi pelaksanaan pemilihan umum bukan satusatunya instrumen demokrasi, konsep demokrasi dan instrumennya telah jauh berkembang.

Pada dekade tahun enam puluhan - tujuh puluhan lahirlah suatu konsep demokrasi yang disebut demokrasi partisipasi. (Akkormans, 1985 : 161, Hadjon, 1999 : 6) dalam konsep demokrasipartisipasirakyat mempunyai hak untukikutmemutuskan(medebleslissingsrecht, dalam proses pengambilan keputusan pemerintahan (Besluitvormingsproces)

Dari berbagai uraian tersebut diketahui bahwa :

1) Setiap kebijakan daerah memerlukan dukungan dan legitimasi rakyat daerah setempat.

2) Legitimasi dan dukungan rakyat daerah dan kualitas kebijakan daerah dapat terealisir apabila rakyat daerah diberikan ruang dan kesempatan yang cukup untuk ikut memutuskan (medebeslissingsrecht), dalam proses pengambilan keputusan pemerintahan (besluitvormingsproces) dalam rangka pembentukan kebijakan daerah.

3) Ciri Demokrasi modern tidak cukup diwakili oleh DPR atau DPRD saja melainkan harus melibatkan rakyat daerah secara proporsional dan komprehensif dalam persiapan, perencanaan, dan implementasi kebijakan daerah yang bersangkutan.

\section{Masyarakat Perlu Dilibatkan dalam Setiap Pembuatan dan Evaluasi Kebijakan Daerah}

Rumusan secara eksplisit tentang asas keterbukaan tidak ditemukan dalam UUD 1945. Namun demikian isu terebukaan dalam pelaksanaan pemerintahan telah merebak di tanah air sejak tahun delapan puluhan dan sebagai realisasi dalam bidang politik dan sosial pada 1986 wakil Presiden membuka kotak pos $5000 .^{13}$

Tanpa keterbukaan tidak mungkin ada peran serta masyarakat. Meskipun segi-segi keterbukaan telah mulai mendapat perhatian namun belum ampak suatu pengaturan dasar tentang makna dan prosedur keterbukaan dalam pelaksanaan pembentukan peraturan perundangundangan. Demikian juga halnya peran serta. Tidak heran kalau ada sementara kalangan lebih mengartikan peran serta sebagai bentuk partisipasi dalam arti gotong royong - peran serta secara fisik. Oleh karena melalui studi perbandingan dengan hukum tata negara dan hukum administrasi Belanda di telaah konsep keterbukaan. Studi perbandingan tidaklah dimaksudkan untuk mengalihkan hukum Belanda ke Indonesia namun lebih-lebih untuk memahami konsep itu dan mudah-mudahan akan dapat mempertajam, konsep kita sendiri.

Pada dasarnya keterbukaan pemerintahan tidak hanya menyangkut informasi. Keterbukaan meliputi keterbukaan sidang-sidang badan perwakilan rakyat, keterbukaan informasi, keterbukaan prosedur, keterbukaan register. Dalam WOB Belanda hanya diatur tentang keterbukaan informasi saja sebagai dasar hubungan antara pemerintahan dan rakyat.

Arti penting keterbukaan dalam sidang-sidang badan perwakilan rakyat berkaitan dengan fungsi pengawasan yang dimiliki badan perwakilan rakyat. Keterbukaan dalam pengambilan keputusan-keputusan politik memungkinkan dan bagi pembuat keputusan akan mendorong sikap berhati-hati dalam pengambilan keputusan.

Dari uraian-uraian tersebut dapatlah diketahui bahwa :

a. Kebijakan daerah dapar berdampak positif dan dapat pula berdampak negatif terhadap daerah maupun rakyat daerahnya

b. Keterbukaan dalam perencanaan, pembentukan dan implementasi sesuatu kebijakan daerah beimplikasi secara langsung maupun tidak langsung terhadap kuantitas dan kualiras kebijakan daerah yang bersangkutan;

13 Soemardjan, 1995, Pilar-Pilar Demokrasi, Pati: Candra Press, Hal 56. 
c. Keterbukaan memberikan akses yang cukup signifikan untuk pendidikan politik rakyat daerah guna menghasilkan kebijakan daerah yang aspiratif, partisipatif dan demokratis.

Dalam sistem ketatanegaraan Indonesia, khususnya dalam hukum tata negara dan hukum administrasi "keterbukaan" merupakan asas penyelenggaraan pemerintahan yang bertumpu atas asas demokrasi (partisipasi). Demokrasi perwakilan sudah lama dirasakan tidak memadai. Pernyataan sepeti yang pernah diucapkan Prof. Mr. R. Boedisoesetio pada pidato inagurasinya sebagai Guru Besar Luar Biasa Hukum Tata Negara dan Hukum Tata Pemerintahan pada Fakultas Hukum Universitas Airlangga yang diucapkan pada hari rabu, tanggal 10 Nopember 1958 kiranya sudah ketinggalam dalam kehidupan modern. Dalam pidato tersebut dikatakan :

Sekali angguta-angguta itu terpilih dan terbentuk DPR, maka rakjat yang berdaulat itu tidak mempujai wewenang lagi untuk menjatakan kemauannja ......

Apabila wacana itu diikuti maka setelah rakyat memberikan suaranya pada (hari pemungutan suara), selanjutnya rakyat itu tidak tahu apa-apa lagi tentang pelaksanaan pemerintahan. Bagi suatu negara demikrasi pelaksanaan pemilihan umum bukan satu-satunya instrumen demokrasi pelaksanaan pemilihan umum bukan satu-satunya instrumen demokrasi. Konsep demokrasi dan instrumennya telah jauh berkembang.

Sesuatu hal yang dirasa atau dipandang sangat penting ialah adanya saluran bagi rakyat untuk menyampaikan aspirasinya melalui DPR. Ketentuan tentang dengar pendapat umum, merupakan sarana yang patut dioptimalkan sehingga pembentukan undang-undang dan perumusan kebijakan lainnya betul-betul mengikutkan masyarakat. (Hadjon, 1999 : 7) Pemerintahan demokratis mengenal adanya keterbukaan informasi yang dibedakan atas keterbukaan aktif dan pasif berkaitan dengan dokumen-dokumen pemerintahan. Keterbukaan informasi dimungkinkan dalam batas-batas tertentu bagi masyarakat untuk mengetahui dokumen-dokumen pemerintah. Fiksi hukum yang mengatakan bahwa "setiap orang dianggap mengetahui undang-undang" tidaklah ada artinya apabila undang-undang tidak dipublikasikan secara luas. ${ }^{14}$

Dalam prosedur pengambilan keputusan pemerintahan baik menyangkut suatu rencana, kebijakan, pembentukan peraturan perundang-undangan maupun suatu keputusan tata usaha negara, (misalnya izin) asas-asas keterbukaan harus dituangkan dalam prosedur tersebut.

Asas keterbukaan dalam suatu prosedur izin, pelaksanaannya dapat berupa :

a. Tersedianya sarana "meedenken en meespreken" baik berupa keberatan, dengar pendapat atau bentuk lain;

b. Pengumuman keputusan izin.

c. Keterbukaan isi permohonan.

Keterbukaan register di Indonesia dikenal antara lain dalam hukum kadaster yaitu keterbukaan buku tanah. Keterbukaan seperti itu di satu pihak memang memberikan informasi kepada masyarakat mengenai hak atas tanah yang sudah didaftarkan dan sekaligus memberikan jaminan perlindungan hukum terhadap hak-hak yng sudah didaftarkan itu.

Salah satu perwujudan asas demokrasi yakni keterbukaan, bahkan merupakan condition sine qua non asas demokrasi. Keterbukaan memungkinkan partisipasi masyarakat secara aktif dalam pembentukan peraturan perundang-undangan.

Asas keterbukaan dalam rangka pembentukan peraturan perundang-undangan yang demokratis, perlu mendapat perhatian, oleh karena demokrasi perwakilan saja dewasa ini tidak memadai.

Dalam rangka hubungan antara pemerintah dan rakyat, kiranya keterbukaan merupakan prioritas pemikiran untuk mendapat perhatian khusus. Kodifikasi hukum administrasi umum,

Duk-Loeb-Nicolai, 1981,Bestuursrecht, Bowar boek, Hal 157. 
khususnya mengenai prosedur pemerintahan seyogyanya perlu mendapat perhatian, yang membuka peluang kodifikasi administrasi secara bertahap. Kodifikasi yang demikian punya arti bagi pelaksanaan asas Negara hukum untuk mewujudkan asas kekuasaan berdasarkan atas hukum secara nyata. Dalam mengantisipasi era globalisasi usaha tersebut perlu medapat prioritas karena hukumlah yang mempunyai peran utama dalam lalu lintas ekonomi global. Pembangunan yang hanya menempatkan posisi hukum sebagai sarana, diragukan kemampuannya untuk mewujudkan Negara Hukum Republik Indonesia yang intinya adalah mewujudkan cita hukum (rechts idee).

\section{Penutup}

\section{Kesimpulan}

Berdasarkan hasil penelitian diperoleh kesimpulan bahwa:

a. Kebijakan-kebijakan menyangkut sektor publik terutama yang berkaitan dengan pembangunan, perlu dirumuskan kebijakan-kebijakan yang benar-benar berangkat dari kondisi Existing yang ada di Kabupaten Sukoharjo.

b. Partisipasi masyarakat mempunyai kontribusi yang cukup signifikan untuk mencegah dan mengiliminir terjadinya praktek KKN dalam pembentukan kebijakan-kebijakan daerah, namun demikian sampai saat ini partisipasi masyarakat tersebut sebagian belum dapat terealisir.

c. Penggunaaan wewenang pemerintahan dalam perencanaan dan pembentukan kebijakan daerah secara tidak tepat dapat berakibat fatal dan kontra produktif dan oleh karenanya pertisipasi masyarakat mutlak diperlukan eksistensinya.

\section{Saran}

Saran yang dapat diajukan dari penelitian ini antara lain:

a. Agar Perda tentang mekanisme pertisipasi masyarakat untuk mengkritisi perencanaan dan pembentukan kebijakan daerah dalam jajaran Pemda Kabupaten Sukoharjo dapat terealisir.

b. Agar ditempuh upaya-upaya kreatif dan dinamis untuk memberdayakan masyarakat guna berpartisipasi mengeleminir dan memberantas praktek-praktek KKN dalam setiap kebijakan daerah baik langsung maupun tidak langsung dalam jajaran Pemda Kabupaten Sukoharjo.

c. Agar jajaran Pemda Kabupaten Sukoharjo dapat memanfaatkan wewenang pemerintahan untuk merencanakan dan membentuk kebijakan secara optimal, tepatm, efektif dan efisien.

\section{Daftar Pustaka}

Badrun, 2003, Mendambakan Pemerintahan Yang Bersih, Jakarta: Pelita Press.

Bardo, 2001, Sistem Kontrol Otonomi, Madiun: CV. Candi.

Duk-Loeb-Nicolai, 1981, Bestuursrecth, Bowar-boek

Santoso, 2001, Hubungan Ideal Pemerintah Pusat dan Daerah, Bandung: Langgeng Press.

Soemardjan, 1995, Pilar-Pilar Demokrasi, Pati: Candra Press

Subardi, 2001, Sistem Otonomi, Surakarta: Cakra.

Suprapto, 2002, Sistem Pemerintahan Nasional, Jakarta: PT. Index.

Supriyadi, 2002, Sistem Partisipasi Moderen, Surabaya: PT. Duta Aksara. 
Sukismo, 2002, Menyimak Otonomi Daerah, Sari Press, Surabaya: Sari Press. Suyudi, 2001, Melacak Liku-Liku Koruptor,Semarang: Candi Press. 